\title{
MANDRAKE FROM ANTIQUITY TO HARRY POTTER
}

\author{
$M$ van den Berg and M Dircksen \\ (North-West University, Potchefstroom)
}

\begin{abstract}
After an introductory paragraph which supplies a cursory overview of all the ancient sources on mandrake, a well known and popular drug amongst the ancients, the article provides a systemization of information obtained from the three most significant ancient accounts of the mandrake plant. Dioscorides' Greek text contains the more precise account and is supplemented by the Latin works of Cornelius Celsus and Pliny the Elder. These authors give detailed information on the plant's physical appearance, the methods employed to harvest it, instructions on how to administer it, the dosages prescribed, the effects of overdosing, its toxicity and its soporific, anesthetic and other (alleged or real) medicinal properties. The second part of the article highlights some literary references to mandrake in sources as diverse as the Bible, a Shakespearean play and Rowling's recent best selling Harry Potter series. Finally a description of mandrake in modern pharmacological terms leads to some conclusions regarding its actual medicinal and homeopathic usefulness.
\end{abstract}

\section{Introduction}

The main focus of this article is an examination of the most important ancient descriptions (200 BC to $650 \mathrm{AD}$ ) of the medical drug known as "mandrake" (Mandragora). All the ancient sources on mandrake are briefly mentioned in the first paragraph. In the systemization of information which follows, the more detailed accounts of Dioscorides (Beck's 2005 translation of the De Materia Medica is used throughout), Celsus and Pliny the Elder provide descriptions of the plant's physical appearance, the methods employed to harvest it, instructions on how to administer it, the dosages prescribed, the effects of overdosing, its toxicity and other (alleged or real) medicinal properties.

The second part of the article highlights some literary references to mandrake in sources as diverse as the Bible, a Shakespearean play and J. K. Rowling's recent best selling Harry Potter series. Finally a description of mandrake in modern pharmacological terms leads to some conclusions regarding its actual medicinal and homeopathic usefulness.

\section{The sources (2000 BC to AD 650)}

Mandrake (Mandragora spp.) has been widely used as a drug throughout antiquity, with the earliest known employment recorded on a cuneiform tablet dated 2000 BC. The ancient Hebrews were well aware of its supposed aphrodisiac, soporific and narcotic properties, and Theophrastus of Eresus (c. 370 - 285 BC) set down descriptions of mandrake's properties (dynamics) as described by his folk-medical informants, the semi-professional root cutters (rhizotomoi). In his Historia 
Plantarum, 9.18, he mentions the drug's common application as a narcotic, but adds a warning that the mandrake root could cause madness. He also relates the rituals and folk-beliefs associated with the gathering of mandragora. References to mandrake are also found in the work of later Greek, Roman and Byzantine pharmacologists and physicians such as Cornelius Celsus (fl. c. 40), Dioscorides of Anazarbus (fl. AD 70), Galen of Pergamon (AD 129 - after 210), Oribasius (AD 325 - 400), Aetius of Amida (AD 500 - 550), and others (Scarborough 2006:02). Non-medical texts likewise refer to mandrake as a drug which was commonly known in classical antiquity and Pliny the Elder's Historia Naturalis of AD 77 compacts numerous earlier accounts (sometimes borrowing from Sextius Niger (fl. AD 30), a writer also used by Dioscorides). Later references to mandrake appear in Apuleius of Madaura's Metamorphoses of c. AD 160, Macrobius' Saturnalia (c. AD 400), Isodore of Seville's Etymologiae of $c$. AD 630, and the so called Herbarium by a pseudoApuleius, dated about AD 650.

Our best and most detailed description of mandrake's pharmacological properties occurs in the De Materia Medica (4.75) of Pedanius Dioscorides. Here one finds a good summary of its uses, occurrences, quantities to be administered, and effects. Dioscorides informs the Roman iatros or medicus that he can expect effects ranging from wooziness to death. It is most significant that Dioscorides specifically mentions that mandrake is an effective anaesthetic.

\section{Recognising the plant}

Dioscorides describes the Mandragora plant as follows: "One kind of this plant is female, the black one, called thridacias, having leaves narrower and smaller than the lettuce's, fetid and heavy in scent, streaming on the ground, and among them fruit resembling sorb apples, pale-green in colour, sweet smelling - containing seed like the pear's. The roots are sizeable, two or three entwined within each other, black on the surface but white inside, having a thick skin. It has no stem. The leaves of the

Masdrazioras mas of fomith. The male and female Mandrake.

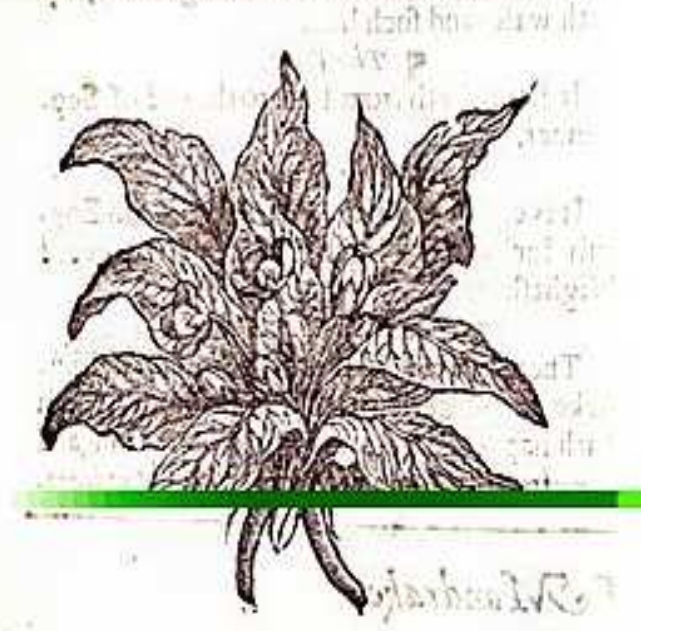
male, the white one, which some called morion, are white, large, broad, and smooth like the leaves of the beet; its fruit is twice as large, saffron in color, and somewhat oppressively fragrant" (4.75.1).

Fig. 1: Graphical picture, from John Gerarde's manual, available in a more recent reprint of 1975 . Cf. http://www. erowid.org/plants/show_image.php?i=man drake/images/archive/mandragora_officina rum_drawing2.jpg. 


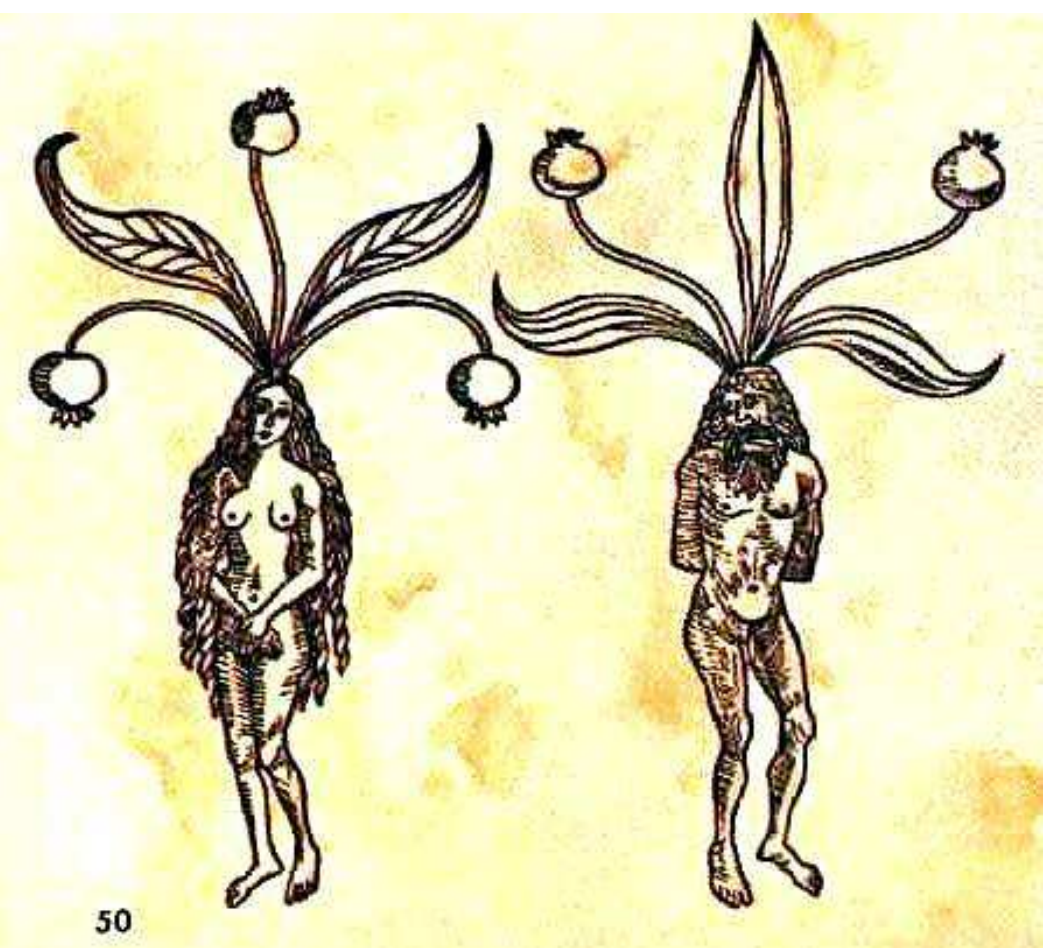

Fig 2: Woodcuts from Hortus sanitatis, 1st edition Mayence, 1485. The mandrake plant was seen either as male or female, according to the bifid taproot of the plant (Schultes 1976:50).

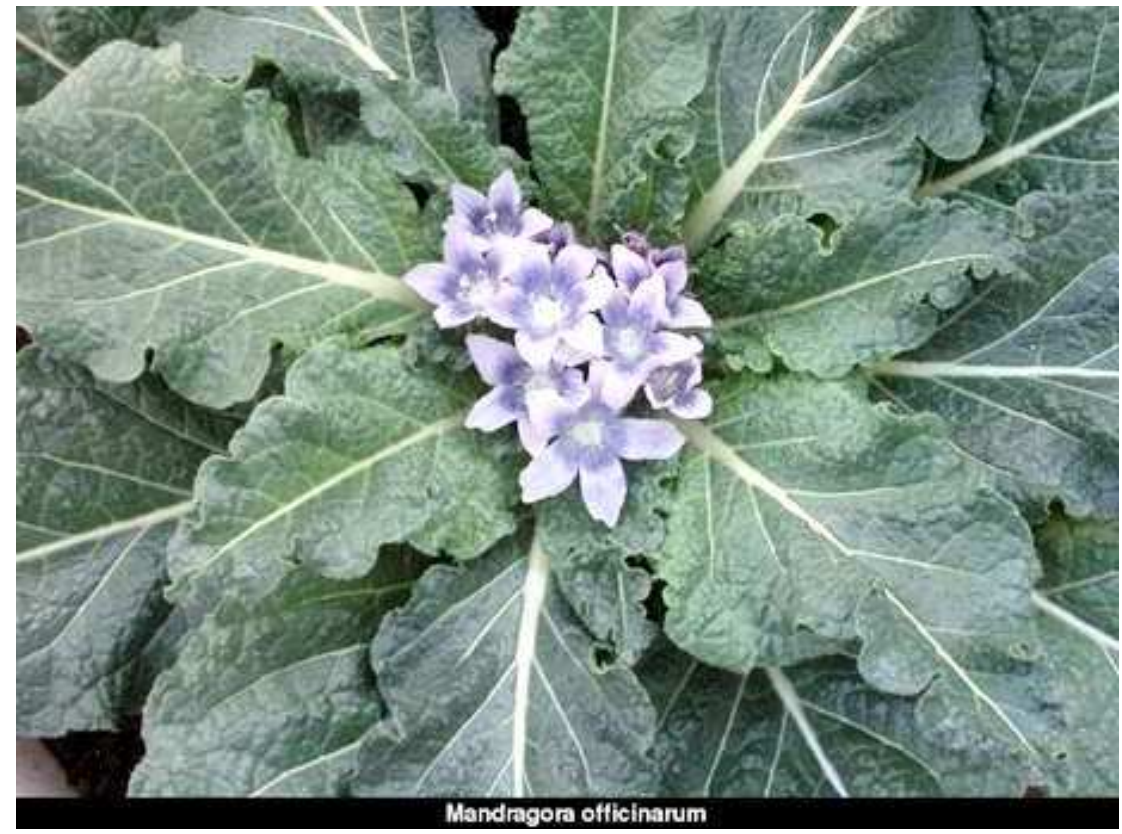

Fig 3: Ayaell. The mandrake leaves and flowers. Erowid.org 2001. http://www.erowid.org/image_url.shtml.

http://www.erowid.org/plants/show_image.php?i=mandrake/images/archive/mandrag ora_officinarum_plant_i2004e0136_disp.jpg. 


\section{Processing the plant}

According to Dioscorides, "juice is extracted from the skin of the root when fresh by chopping it and putting it under a press. After it has been condensed, it must be stored in a clay vessel. Juice is extracted also from the fruit in a similar fashion, but the juice from the fruit becomes weak. The skin is also peeled from the root, threaded with a linen thread, and hung for later use." He adds that some users boil the roots in wine until the fluid has been reduced to one third of its original volume. This decoction is then strained and stored (4.75.3).

\section{The effects of mandragora}

Dioscorides gives a full description of the dosage and ailments for which it was used:

... administering about one cyathus to insomniacs, to those in much pain, and those undergoing surgery or cauterization whom they wish to anesthetize. A quantity of two obols of its juice drunk with hydromel brings up phlegm and bile as hellebore does; but when too much is drunk, it is lethal.

It is compounded with ophthalmic and analgesic medications and with emollient pessaries; about one hemiobolon inserted by itself as a pessary, draws the menstrual period and embryos/fetuses; and when placed in the anus as suppository, it is soporific ... The leaves, when new, are suitable plasters with barley groats both for the inflammations of the eyes and for inflammations of sores; they dissipate all indurations and abscesses, scrofulous swellings of the glands, growths, and when gently rubbed on for five or six days, erase blemishes without ulceration; the leaves are also put up cured for the same uses.

The root, grounded up with vinegar, cures erysipelas, ${ }^{1}$ it is good with either honey or oil for strokes (bites) of reptiles, with water it disperses scrofulous growths and tumors, and with barley groats it puts and end to pains in the joints $\ldots$ give three cyathoi $(0,04561)$ of it to those about to undergo surgery or cautery, as indicated above. For they become unaware of the pain because they sink in a deep sleep.

Its fruit is soporific when eaten as well as when smelled, as is also its juice, but consumed in excesses, it even makes people unable to speak. The seed of the fruit cleanses the uterus when drunk and it stops the red discharge when inserted with native sulfur ...

Some note that there is yet another morion ... they say that it stupefies when as much as one drachma is drunk or when eaten in a lump of barley or in prepared food; for the person falls asleep in whatever posture he was when he ate it, feeling nothing for three or four hours from the time it was offered to him.

Erysipelas (Greek $\varepsilon \rho v \sigma i ́ \varepsilon \varepsilon \lambda \alpha \varsigma$ - "red skin"). A superficial cellulitis caused by Group A $\beta$ hemolytic streptococci. Cf. Berkow et al. 1987:2265). 
Physicians about to perform surgery or cautery use this one, too. They say that the root is also an antidote when drunk with thorn apple (4.75.3-7).

They say that it (wine flavoured with mandrake) is soporific and that it plunges an entire dinner party into deep sleep if one cotyle $(0,2741)$ of it was mixed with one chous $(3,2821)$ of wine; one cyathos drunk with one xestes $(0,5471)$ of wine is lethal. Both when smelled and when used as a clyster it does the same (5.71).

According to Celsus 3.18.12 one can put the mandrake apples under the pillow to cure insomnia. ${ }^{2}$ We also read in Celsus that mandrake was an effective cure for headache, ulceration, ophthalmia, toothache, difficulty in breathing, intestinal gripings (cramps), inflammation of the womb, pain in the hips, liver, spleen or ribs, or, when owing to genital trouble, a woman collapses speechless, the mandrake mix was effective as a sedative (5.25.3). ${ }^{3}$ There was also a very effective mandrake ointment, which was applied above the eye in case of infection (6.6.1). ${ }^{4}$ Celsus tells us that, dissolved in water and taken orally, mandrake could be used as a painkiller. One could also eat a piece of white bread which has been soaked in the mix (Cels. 5.25.3).

2 Si nihilo minus vigilant, quidam somnum moliuntur potui dando aquam, in qua papaver aut hyoscyamos decocta sint, alii mandragorae mala pulvino subiciunt, alii vel amomum vel sycamini lacrimam fronti inducunt (Cels. 3.18.12). If in spite of this patients are wakeful, some endeavor to induce sleep by draughts of decoction of poppy of hyoscyamus; others put mandrake apples under the pillow; others smear the forehead with cardamom balsam or sycamine tears. Cf. Spencer 1935:295.

3 Sive autem capitis dolores sive ulcera sive lippitudo sive dentes...sive spiritus difficultas sive intestinorum tormenta sive inflammatio vulvae est, sive coxa sive iecur aut lienis aut latus torquet, sive vitio locorum aliqua prolabitur et ommutescit, occurrit dolori per quietem eiusmodi catapotium: silis, acori, rutae silvestris seminis, singulorum P. * I; castorei, cinnamomi, singulorum $P$. * II; papaveris lacrimae, panacis radicis, mandragorae malorum aridorum, iunci rotundi floris, singulorum P. * II = -; piperis grana LVI. Haec per se contrita, rursus instillato subinde passo, simul omnia teruntur, donec crassitudo sordium fiat. Ex eo paululum aut devoratur, aut aqua diluitur et potui datur (Cels. 5.25.3). But whether there is headache or ulceration or ophthalmia or toothache or difficulty in breathing or intestinal gripings or inflammation of the womb or pain in the hips or liver or spleen or ribs, or, whether owing to genital trouble, a woman collapses speechless, a pill of the following kind counteracts pain by producing sleep: saxifrage, sweet flag, wild rue seed, 4 gr. each, castory and cinnamon 8 gr., poppy-tears, panax root, dried mandrake apples, flowers of the round rush, 9 gr. each, and 56 peppercorns. These are first pounded separately, then rubbed up all together, whilst gradually adding raisin wine until the mixture is of the consistency of sordes. A small quantity is either swallowed or dissolved in water and taken as a draught. Cf. Spencer 1935:60.

Aliud ad idem: murrae P. * -; mandragorae suci P. * I; papaveris lacrimae P. * II; foliorum rosae, cicutae seminis, singulorum P. * III; acaciae P. * IIII; cummis P. *VIII. Et haec quidem interdiu: nocte vero, quo commodior quies veniat, non alienum est superinponere candidi panis interiorem partem ex vino subactam (Cels. 6.6.1.I). Another composition having the same efficacy is made up of: myrrh 0.33 gr., mandragora juice 4 gr.; poppy-tears 8 gr.; rose-leaves and hemlock seeds 12 gr. each; acacia 16 gr.; gum 32 gr. These applications are made by day; at night, in order better to assure sleep, it is not inappropriate to apply above the eye, the crumb of white bread soaked in wine. Cf. Spencer 1935:190. 
Pliny the Elder and his sources prescribe a drink of two oboli to purge the body and to help against nausea. ${ }^{5}$ According to him, the mere smell causes heaviness of the head (which intensifies when a person wakes up) and - although in certain countries the fruit is eaten - those who in ignorance breathe in too much of its vapor are struck dumb, while too copious a draught even causes death. When the mandrake is used as a sleeping draught, the quantity administered should be proportionate to the strength (health) of the patient, a moderate dose being one cyathus (one glass full). It is also taken in a liquid form for snake bite, and before surgical operations and punctures to effect anesthesia. Some find that merely sniffing the drug is sufficient to put them to sleep. When too much is consumed (cyathus or more) the user will die (Plin. HN 25.94).

\section{Literary references}

One of the earliest literary references to mandragora is found in the Bible (c. $1250-1200$ BC). Rachel and Leah firmly believed that mandrake would increase fertility. In Genesis 30 we read that Rachel pleaded with Leah to give her some mandrake. Leah's son Reuben had brought it home from the field. It seems that mandrake was in great demand, for Leah replied: "Is it a small matter that you have taken away my husband? Would you take away my son's mandrakes also?" Rachel was willing to compromise: "Then he (i.e. Jacob) may lie with you tonight for your son's mandrakes." When Jacob came home Leah greeted him with the words: "You must sleep with me, I have hired you with my son's mandrakes." Their belief in mandrake as a fertility drug was reinforced, since Leah had a son and after that a daughter and Rachel was also later blessed with a son (Gen. 30:14 ff). Song of Songs records its properties as an aphrodisiac:

\section{mandragorae dederunt odorem in portis nostris omnia poma nova et vetera dilecte mi servavi tibi}

The mandrakes give forth fragrance, and over our doors are all choice fruits, new as well as old, which I have laid up for thee, O my beloved (7:13).

The mandrake's fruit was seen as love apples, which formed on the root. Consumption of the apples led to increased sexual desire. In portis nostris suggests that after a night in the fields and the walk in early morning, it is time to go back home.

Flavius Josephus (AD 37 - 101) warned against the poisonous effects of the plant in The Jewish war written in AD 78:

$\alpha$ $\tau \eta \eta \eta$

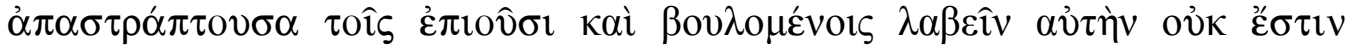

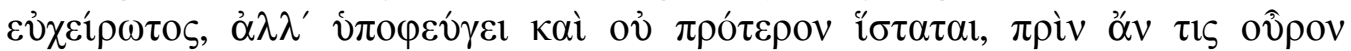

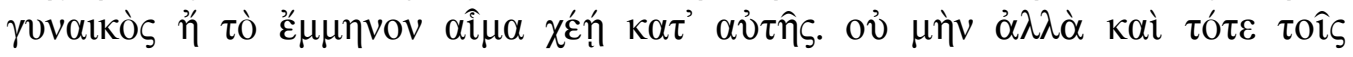

\footnotetext{
5 An obolus is an ancient unit of weight equal to one sixth of a drachma i.e. 0,568 gr.

6 Here and elsewhere the Revised Standard Version of the Bible has been used.
} 


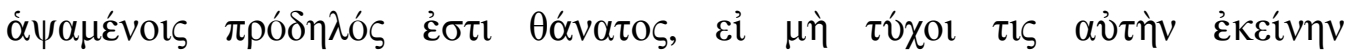

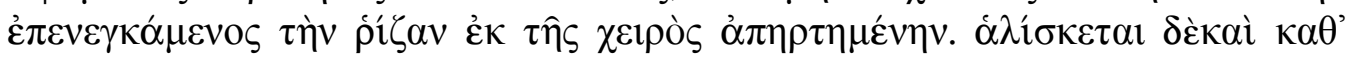

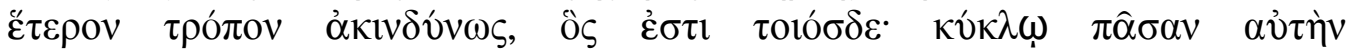

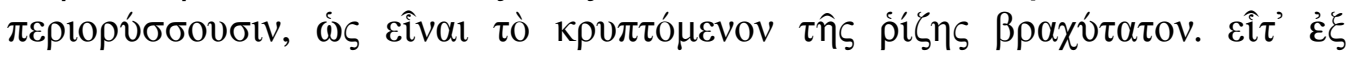

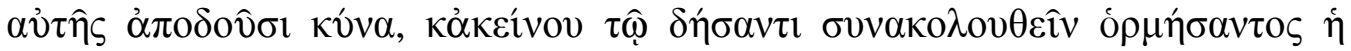
$\mu \grave{\varepsilon} \nu(7.180)^{7}$

Flame-colored and towards evening emitting a brilliant light, it eludes the grasp of persons who approach with the intention of picking it, as it shrinks up and can only be made to stand still by pouring upon it certain secretions of the human body. Yet even to touch it is fatal, unless one succeeds in carrying off the root itself, suspended from the hand. Another innocuous mode of capturing it is as follow. They dig all round it, leaving but a minute portion of the root covered; then they tie a dog to it, and the animal rushing to follow the person who tied him easily pulls it up, but instantly dies (Thackeray 1928:557).

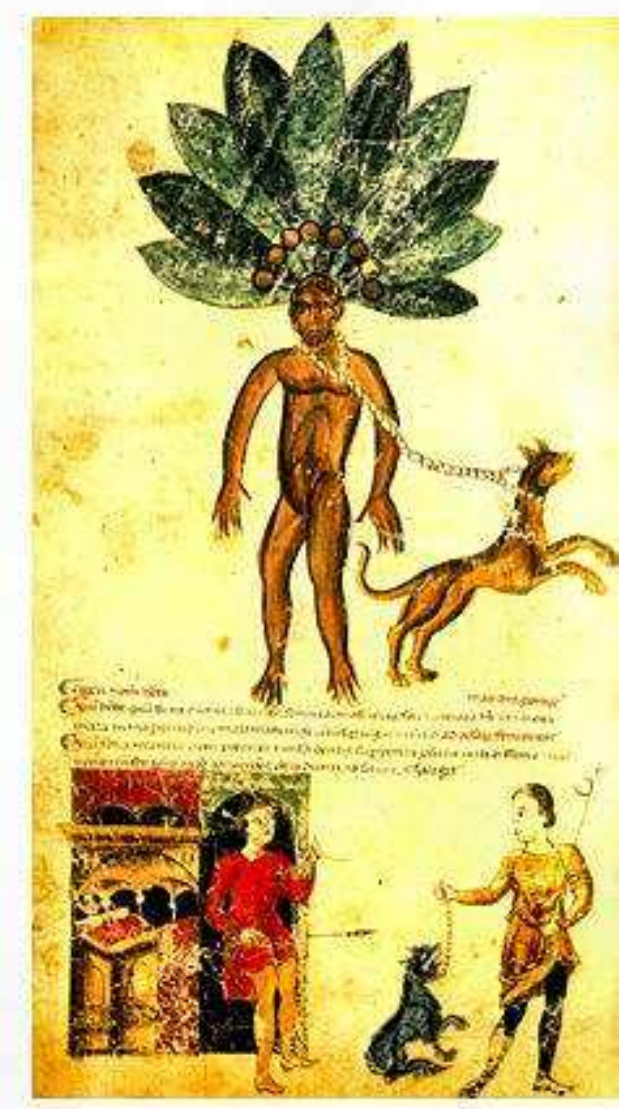

MEDICINA ANTIQUA: LIBRI QUATTUOR MEDICINAE, $13 T H$ CENTURY.

Codex Vindobonensis 93. Facsimile. (Washington University, Becker Library)

Fig 4: A graphical picture of a dog pulling mandrake out of the ground (Carter 2003:145).

Cultural Heritage Literature Technologies - Perseus Digital Library.

http://www.chlt.org/sandbox/perseus/j.bj_gk/page.106.a.php?size=240x320 
Frontinus (c. 40-103) wrote that Hannibal of Carthage also used mandrake as a narcotic in military fights against the rebels in Africa (Frontinus Strategems 2.5.12). Maharbal knew that the African tribe was passionate about their wine, so he mixed a large quantity of mandrake with wine. This mixture would induce sleep and in large quantities it could even be fatal. When the rebels surrounded the camp at nighttime and found the wine, they drank the wine greedily instead of invading the camp and attacking Maharbal. When Maharbal returned to the camp, everyone lay stretched out as if they were dead.

In the following extract from Apuleius (AD 123-180) Metamorphoses 10.11, the hypnotic effect of the mix of mandrake and wine is briefly described. In this scene, everyone seems to know the properties of mandrake. When a scoundrel of a slave wanted to buy some kind of poison, the physician gave him mandrake.

Dedi venenum, sed somniferum, mandragoram illum gravedinis compertae famosum et morti simillimi soporis efficacem ... Sed si vere puer meis temperatam manibus sumpsit potionem, vivit et quiescit et dormit, et protinus marcido sopore discusso remeabit ad diem lucidam (Ap. Met. 10.11).

I gave him a drug, but a soporific, mandragora, well known for its proven lethargic effect, which produces a coma very much like death ... However, if the boy really took the medicine that I mixed with my own hands, he is alive and resting and sleeping, and he will soon shake off his languid coma and return to the light of day (Hanson 1989:224).

In the Middle Ages mandrake became especially popular as a magical plant, and was seen as a miracle talisman, capable of curing just about anything. It was the root in particular that emanated this mysterious power to fascinate and entrance people - most likely due to its shape, which seemed to resemble a human body. These magical roots came either as "Mandrake women" or "Mandrake men", depending on their shape, but either way they were thought to be powerful allies who could perform true miracles for their masters - anything from attracting love where previously there was none, to getting rich quick, striking unsuspected luck, warding off misfortunes and evil spells or becoming invincible in battle.

William Shakespeare seems to have been quite familiar with mandrake. His works contain several references to mandragora's use as a sedative, ${ }^{8}$ a charm ${ }^{9}$ or as curse. ${ }^{10}$

During this time, it was, however, still known as a fertility drug. In 1518 Machiavelli wrote a play La Mandragola (The Mandrake, first printed in 1524) in which the plot revolves around Callimaco who used a mandrake potion as a ploy to bed Nicia and cause her to fall pregnant.

Mandrake and its magical powers even resonate in Rowling's recent best selling Harry Potter series. In the Hogwarts Greenhouse, Harry Potter and fellow students are taught how to repot mandrake. Their herbology lecturer, professor Sprout questions the class about the properties of mandrake. Hermione answers: "Mandrake, 
or Mandragora, is a powerful restorative ... it is used to return people who have been transfigured or cursed to their original state". Professor Sprout adds: "Mandrake forms an essential part of most antidotes. It is also, however, dangerous". Hermione explains this danger: "The cry of the mandrake is fatal to anyone who hears it" (Rowling 1998:72).

Professor Sprout ordered each pupil to take a pair of earmuffs, which they had to wear when told to. They had to take care that their ears were completely covered when she gave them the thumbs up.

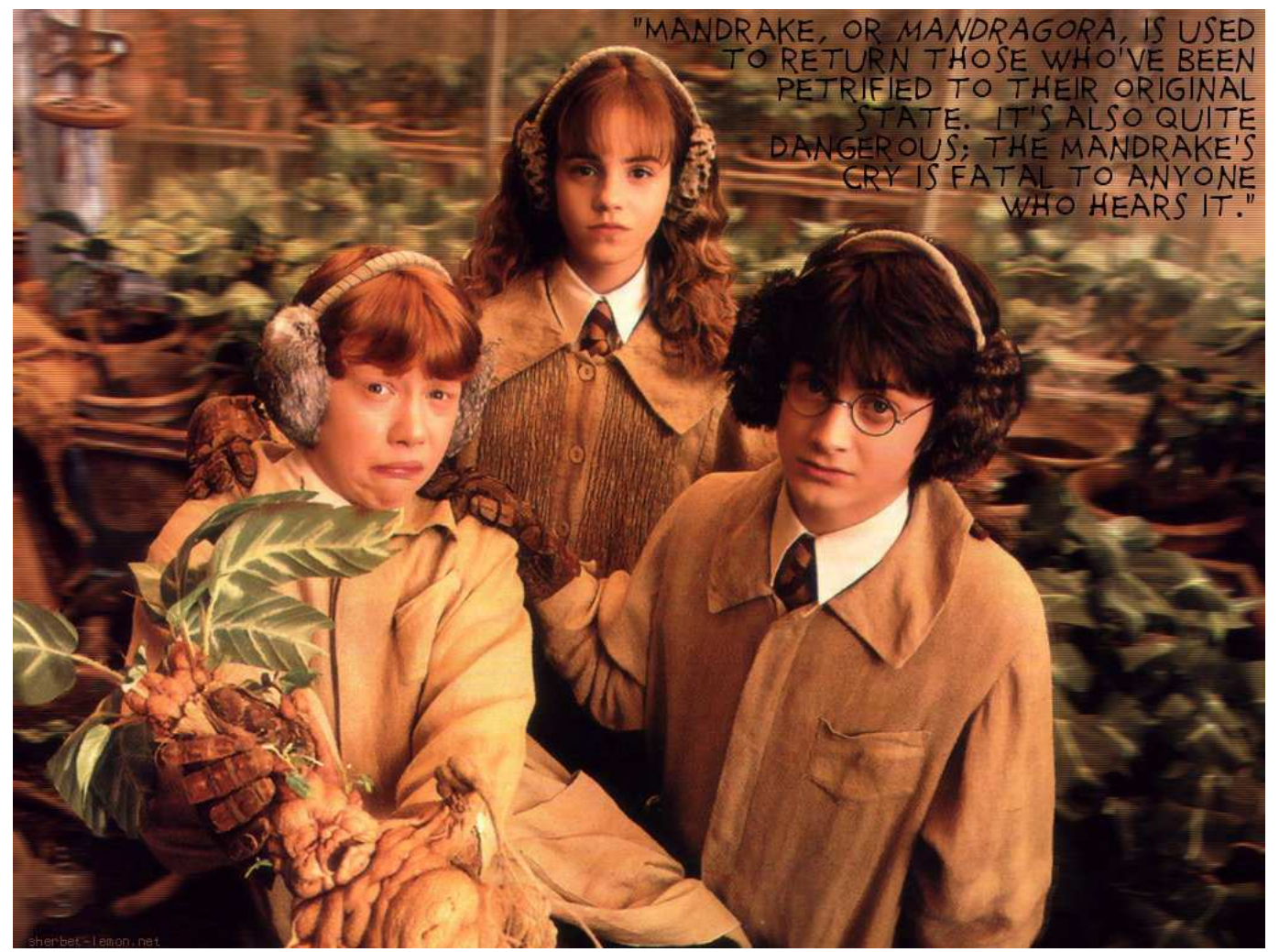

Figure 5: Harry Potter, Hermione and Ron holding a mandrake plant. ${ }^{11}$

Then she grasped one of the tufty plants firmly, and pulled hard. "Instead of roots, a small, muddy and extremely ugly baby popped out of the earth. The leaves were growing right out of his head. He had a pale green, mottled skin, and was clearly bawling at the top of his lungs".

Professor Sprout then took a large plant pot, plunged the mandrake into it, and buried him in the damp compost until only the leaves were visible. She dusted her hands and took off the earmuffs. "As our Mandrakes are only seedlings, their cries won't kill yet," she said calmly. "However, they will knock you out for several hours".

Rowling wrote fiction, but this scene proves that a surprising amount of research went into her work. The plant she describes has human qualities, it screams

11 http://www.sherbet-lemon.net/wp.php 
when pulled from the earth, it is also magical, can "knock you out" and taken in large quantities it can prove to be fatal.

\section{Modern description}

Phytochemical analysis assumes that the phytochemical properties of crude drugs have predictable physiological effects in the living human organism. Mandragoras officinarum belongs to the Solanaceae family of plants and contains $0,3-4 \%$ of tropane based alkaloids. An alkaloid denotes all complex basic nitrogenous compounds of vegetable origin, processing a physiological action. It contains carbon, hydrogen, nitrogen and oxygen in its molecules and is a well-defined crystalline substances (Evans 1996:605). The alkaloids in mandrake are hyoscyamine $\mathrm{C}_{17} \mathrm{H}$ ${ }_{23} \mathrm{O}_{3} \mathrm{~N}$ (scopoletin $2500-3500 \mathrm{ppm}$ ), hyoscine $\mathrm{C}_{17} \mathrm{H}_{21} \mathrm{O}_{4} \mathrm{~N}$ (scopolamine $30-50$ ppm), atropine $\mathrm{C}_{17} \mathrm{H}_{23} \mathrm{O}_{3} \mathrm{~N}(10-20 \mathrm{ppm})$ and small quantities of mandragorine that is only found in the root (Ramoutsaki et al. 2002:336). Tropane alkaloids $(3,6-$ ditigloxytropane) are esters of various tropic acids and derivatives of pyrrolidinepiperidine alkaloids. Hyoscyamine and scoplamine are also the main active ingredients in Datura stramonium and Atropa belladonna.

Mandrake is not used in modern pharmaceutics any longer, but chemical drugs are available which include the active ingredients also found in mandrake, such as hyoscyamine and scopolamine (Van Wyk et al. 2004:416).

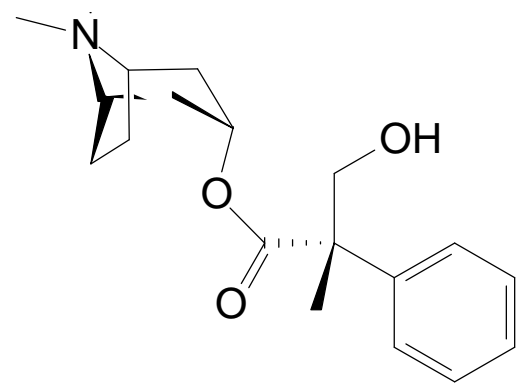

Fig 6: The chemical structure of (S)-Hyoscyamine (Hoffmann 2003:123)

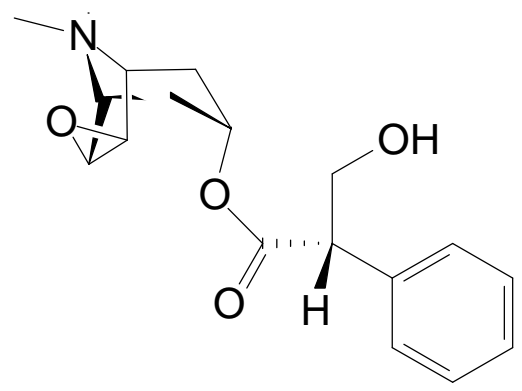

Fig 7: The chemical structure of (S)-Scopolamine (Hoffmann 2003:123) 
These active ingredients are still used to induce sleep and as a narcotic before surgery, producing unconsciousness and indifference to pain. It is also used as an antispasmodic and an emetic. Before eye surgery it is used to enlarge the pupil (mydriatic effect), and it is valuable in the treatment of asthma, hay fever and coughs (Brown et al. 1996:141).

\section{Pharmacology}

A prominent feature of the tropane alkaloids is their ability to produce hallucinations and delirium (Hoffmann 2003:123). The alkaloids act as vasodilators and are used in cough medicines to open the bronchi (Scarborough 2002:187). Hay fever is cured by the vasodilating (opening) of the vessels as well as the respiratory system. Nasal and sinus secretions caused by allergies and colds are also decreased.

High doses atropine and hyoscyamine are central acting and strong antagonists (muscarinic acetylcholine receptors). They lead to depression of respiration and induce coma due to the stimulation of the cerebrum, midbrain and medulla oblongata. It inhibits smooth muscle and is classified as a spasmoliticum that leads to hallucinogenic activity in the central nervous system (Brown et al. 1996:160).

The atropine causes dilatation of the pupil of the eye - mydriatic alkaloids help prevent adhesions between the iris and lens of the eye during iritis (Brown et al. 1996:151).

Hyoscine affects memory and central respiratory depression in high doses during anesthesia.

Hyoscyamine also controls abdominal and visceral cramps, gastric secretions during peptic ulcer therapy, hypermotility in spastic colitis. It reduces tremor and rigidity in Parkinson's disease (Harbone et al. 1993: 229).

Atropine, as well as hyoscyamine, is an anticholinergic agent. Atropine suppresses salivation and is used during anesthesia to reduce secretions (Hoffmann 2003:123).

Hyoscine (scopolamine) prevents motion sickness.

\section{Toxicicity}

When too much of this specific drug is consumed, side effects potensiate until the whole human system gets contaminated. It leads to a dry mouth and rapid heart beat. Neurologically it causes sedation, central motor depression, twilight sleep instead of excitation and delirium. Skin rush, flushing, painful urination, blurred vision and light sensitivity are also symptoms that can occur during the use of atropine (Hoffmann 2003:123). 


\section{Conclusion}

Throughout the long history of botany and pain relief, mandrake has been used as an effective anodyne, soporific and hallucinogenic agent. Towards the middle ages its magical properties seem to have been highlighted although it was still regarded as a sedative and fertility enhancer. When analyzed in modern terms, it becomes clear that its use as a narcotic, for cramps, against nausea and snakebites as described by the ancient authors was fully justified. It was also effectively used in eye medication and flu-mixes because it is a vasodilator that opens the bronchi, especially in cases of asthma and to relieve coughs. According to the pharmacology however, its use as an enhancer of fertility is not proven, unless improved blood flow to the reproductive system is considered conducive to conception.

\section{BIBILIOGRAPHY:}

Beck, L Y 2005. Pedanius Dioscorides of Anazarbus: De Materia Medica. Hildesheim: Olms-Weidemann.

Bennet, C E 1925. Frontinus: Strategems. Loeb Text. London: Heinemann.

Berkow, $\mathrm{R}$ et al. 1987. The Merck manual of diagnosis and therapy. New Jersey: Rahway.

Brown J H \& Taylor P 1996. Muscarinic receptor agonists and antagonists. In Hardman J G \& Limbird L L (eds). Goodman and Gilman's Pharmacological Basis of Therapeutics, $9^{\text {th }}$ ed., 141-160. New York: Mc Graw-Hill.

Carter, A C 2003. Myths and mandrake. Journal of the Royal Society of Medicine 96:144 - 147.

Einarson, B \& Link, G K K 1976 - 1990. Theophrastus: Historiae Plantarum. Loeb Text. Cambridge: Harvard University Press.

Einarson, B \& Link, G K K 1976-1990. Theophrastus: De Causis Plantarum. Loeb text. Cambridge: Harvard University Press.

Evans, W C 1996. Trease and Evans' Pharmacognosy. London and Philadelphia: Saunders.

Gutstein, H B \& Akil, H 2001. Opioid Analgesics. In Hardman J G and Limbird L L (eds.). Goodman and Gilman's Pharmacological Basis of Therapeutics, 569619. New York, Mc Graw-Hill.

Hanson, J A 1989. Apuleius: Metamorphoses Volume II. Loeb text. Cambridge: Harvard University Press.

Harbone, J B \& Baxter, H 1993. Phytochemical Dictionary: A handbook of bioactive compounds from plants. London; Washington, DC: Taylor \& Francis.

Hoffmann, D 2003. Medical Herbalism: The science and practice of herbal medicine. Vermont: Healing Arts Press.

Jones W H S 1956. Plinius the Elder: Naturalis Historiae. Loeb Text. Cambridge: Harvard University Press. 
Ramoutsaki, I, Askitopoulou, A \& Konsolaki, H E 2002. Pain relief and sedation in Roman Byzantine texts: Mandragoras officinarum, Hyoscyamus niger and Atropa belladonna, 43-50. In Diz, J C, Franco, A, Bacon, D R, Repreht, $\mathrm{J} \&$ Alvarez, J (eds). The History of Anesthesia; Proceedings of the 5th International Symposium on the History of Anesthesia, Santiago, Spain 19-23 September 2001.

Rowling, J K 1998. Harry Potter and the chamber of secrets. London: Bloomsbury. Scarborough, J (et al.) 2002. Byzantine Garden Culture: Herbs of the field and herbs of the garden in Byzantine medicinal pharmacy. Washington: Dumbarton Oaks.

Scarborough, J 2006. Mandrake in ancient surgery. Society for ancient medicine. Medicine meeting at the annual meeting of the American Philological Meeting in Montréal, Québec 7 January 2006.

Schultes, R E 1976. The Golden Guide - Hallucinogenic Plants. New York: Western Publishing Company, Inc. Published by Golden Press.

Spencer, W G 1935. Celsus: De Medicina. Loeb Text. London: Heinemann.

Thackeray, H St J 1927. Josephus: The Jewish war. Loeb Text. Cambridge: Harvard University Press.

Van Wyk, B E \& Wink, M 2004. Medicinal plants of the world. Pretoria: Briza Publications. 